\title{
Satisfaction Level of Higher Education Graduates in the Industrial Revolution Era 4.0
}

\author{
Subur ${ }^{1}$, Imam Mawardi $^{2}$, Akhmad Baihaqi $^{3}$ \\ \{subur@ummgl.ac.id ${ }^{1}$ \} \\ Islamic Education Department, Universitas Muhammadiyah Magelang, 56172, Indonesia ${ }^{1,2,3}$
}

\begin{abstract}
To realize the Vision and Mission to become a Excellent and Islamic University Universitas Muhammadiyah Magelang establish a long term plan 2020-2024 in six stages. One of the stages is strengthening of national competitiveness and initiating internationalization. The intended national competitiveness is quality of graduate. The research aims to determine the level of satisfaction of graduate users to developing a curriculum and relevance to the business and the industrial world. The method used in this research is descriptive qualitative. The population was taken from 1359 graduates in 2018 with a total sample size of 160 graduate users who filled out surveys in 2020. The technique of collecting data is through filling out an online survey tracer study on the website. Six variables studied from integrity, professionalism, ability use of information technology, communication skills, teamwork and self-development showed very good or high results with an average of $38 \%$ and good or moderate categories of $57 \%$ and $5 \%$ enough or low. The survey results that the English proficiency of graduates is low, $12.50 \%$ or 20 people who are declared very good or high and $45 \%$ or 72 people then there are $35 \%$ or 56 people who are categorized good and 6.88 . \% or 11 people with low or poor ratings. This shows that graduates users are not satisfied with the graduates' English skills. Even at this point, the response from graduate users clearly mentions that graduates have poor English skills.
\end{abstract}

Keywords: Satisfaction, Level Higher Education, Industrial Revolution Era 4.0.

\section{Introduction}

Universities are educational institutions that give birth to human resources in the form of graduates who are expected to be ready to be absorbed by the community as users [1]. Human resources for the owners and managers of tertiary institutions, the quality management system is essentially at the core of continuous improvement to strengthen and develop the quality of graduates so that they can be absorbed by agencies and the labor market [2], [3].

Graduates who are well absorbed in the market, whether they are entrepreneurial or work with other people, are able to become the basis for whether the existence of the institution will 
be maintained or not. How much higher education alumni are able to take part in development according to the relevance of their education can be carried out by tracing their graduates [4].

Therefore, to produce high quality alumni, it is required to be able to develop the potential of higher quality students in accordance with the quality that has been set. To realize the Vision and Mission of becoming a Superior and Islamic University, Universitas Muhammadiyah Magelang has set the 2020-2044 Long Term Plan in 6 stages. One of the stages is the strengthening of national competitiveness, namely the quality of graduates. To find out the quality of graduates, it is necessary to carry out tracer studies or graduate tracking activities that are focused on graduate users with the aim of extracting information from alumni / graduate users regarding the development of competencies needed by the job market for curriculum improvement in the era of the industrial revolution 4.0.

However, in order to achieve graduates with qualifications in accordance with market needs and global competition in the current era of the Industrial Revolution 4.0, tracer study activities are needed [5]. The information obtained from tracer studies is very useful for various evaluations of higher education outcomes, improvement and assurance of the quality of higher education institutions and the relevance of higher education, information for stakeholders, and requirements for accreditation of higher education[6].

The quality of the institution will determine the success of the learning process for students. With good quality, it is expected to be able to produce a generation capable of being smart professionals and able to keep up with the times and remain relevant to progress. With good quality, it will make graduate users feel satisfied and appreciate the skills and skills of graduates in the world of work. Conversely, without the ability of alumni to work, it causes user dissatisfaction. This can be due to the irrelevance of the curriculum being taught to the challenges and dynamics of the world of work. The purpose of the graduate use tracer is to collect relevant information and input from graduates related to the "learning and working experience" experienced by graduates for the development of higher education [7].

From the background of the problem, it can be formulated the problem of the level of satisfaction of the graduate users of the alumni of the Muhammadiyah University of Magelang. The purpose of this study was to determine the absorption, process, and position of graduates in the world of work, evaluation of higher education outcomes and subsequently can be used to improve and guarantee the quality of higher education institutions and to refine the curriculum at the University of Muhammadiyah Magelang, and to provide information about the relationship between higher education and the world of professional work, assessing the relevance of higher education, information for stakeholders.

Several studies that have been carried out on graduate user satisfaction include [8]. which describe and analyze the level of satisfaction of PLS students with educational services at FIP UNNES, and the level of user satisfaction with graduates. Research by Mahendra (2012) which discusses "User Satisfaction Study of Graduates of the Building Engineering Education Study Program, Department of Civil Engineering, FT UNJ (Case Studies in Formal and Non-Formal Educational Institutions in Jabodetabek) in 2012. Research from Agustin (2017) discusses" Analysis of the Readiness of Graduates of the Building Engineering Education Study Program, Faculty of Engineering, State University of Jakarta in the Field of Work.

This research study aims to determine the level of user satisfaction of graduates in 2018 in order to develop a curriculum and its relevance to the world of business and industry through a survey on graduate user satisfaction, graduate competence and user suggestions for competency improvement. Some of the things that will be surveyed are integrity, expertise based on scientific fields, English language skills, the ability to use information technology, 
communication skills, work motivation, work ethic, problem solving skills, broad insight between disciplines and teamwork.

\section{Method}

Based on the objectives to be obtained in this study, this study uses a descriptive approach. This is intended to provide solutions to problems that exist today. This research has stages of data collection, data analysis, making conclusions and reports. The method used was a survey with a stratified proportionate random sampling technique with a minimum sampling rate of $20 \%$ of the graduate population. The population was taken from graduates in 2018 as many as 800 graduate users with a total sample of 160 graduate users who filled out the survey from August to October in 2020. The research variables used included integrity (ethics and morals), professionalism (suitability between fields of science), English proficiency, ability to use information technology, communication skills, teamwork and self-development. The research instrument is a tool that will be used for research data collection. The instrument used was a survey questionnaire sheet for 160 users. The data collection technique was through filling out the survey tracer study form online on the website. After obtaining the data, the data will be entered in excel and then made percentages and graphs to make it easier to read the results.

\section{Results and Discussion}

\subsection{User tracer stages graduates}

Graduate User Tracer activities are carried out in several stages, namely the preparation, implementation and reporting stages with detailed explanations as follows. The preparation stage is carried out through various activities, including: cohorts, questionnaires, alumni update data, graduate user data, appeal letters. This stage is carried out after carrying out the preparation stage. This stage is done by taking several steps; outreach, survey starts, reminder 1-3, survey is closed. The reporting stage is carried out after the questionnaire is collected as a whole or meets the standards of data collection, with the following activities: Of the 800 alumni in 2018 , there were 160 graduate users who filled out the survey with the following results in Table 1. Result survey in below:

Table 1. Result survey evaluation aspect

\begin{tabular}{lcccc}
\hline \multicolumn{1}{c}{ Aspects of the Assessment } & Very Good & Good & Sufficient & Less \\
\hline Integrity (Ethics and Morals) & $49.38 \%$ & $48.13 \%$ & $2.50 \%$ & $0.00 \%$ \\
Expertise based on the field of & $41.25 \%$ & $55.63 \%$ & $3.13 \%$ & $0.00 \%$ \\
science (professionalism) & & & & \\
English language skills & $12.50 \%$ & $45.00 \%$ & $35.63 \%$ & $6.88 \%$ \\
Use of information techno & $37.50 \%$ & $55.63 \%$ & $6.88 \%$ & $0.00 \%$ \\
Communication skills & $36.25 \%$ & $60.63 \%$ & $3.13 \%$ & $0.00 \%$ \\
Teamwork & $38.75 \%$ & $58.13 \%$ & $3.13 \%$ & $0.00 \%$ \\
Self-development & $26.88 \%$ & $66.88 \%$ & $6.25 \%$ & $0.00 \%$ \\
\hline
\end{tabular}




\subsection{User tracer result graduates}

a. Ethical and moral integrity

The results showed that graduate users gave good and very good categories to graduates, namely having integrity with very good categories of $49.4 \%$ and good categories of $48.1 \%$, and only $2.5 \%$ or about 4 alumni who got sufficient grades. it shows that the level of success of the university in imparting soft skills and ethics is very high.

b. Expertise based on the field of science

The graduate users gave an assessment to alumni who work in their company/ institution with a very good category of $41.25 \%$ or a total of 66 alumni, while in the good category it was $55.63 \%$ or 89 alumni and $3.13 \%$ with a sufficient score of 5 person. Expertise in the field of science is the match between the curriculum being taught and the needs in the world of work

c. English language skills

The survey results obtained show that the English proficiency of graduates or alumni is low, namely $12.50 \%$ or 20 people who are declared very good and 72 people are good, then there are 57 people with a fairly good category and $6.88 \%$ or 11 people with poor ratings. or bad. This shows that alumni users are not satisfied with the graduates' English skills. Even at this point, the response from graduate users clearly mentions that graduates have poor English skills

d. Ability to use information technology

Based on the data analysis, it was found that the graduate users gave a very good rating of $37.50 \%$, namely 60 people, $55.63 \%$ were good, and quite good was $6.88 \% \mathrm{~g}$. This means that in terms of the ability to collect information, it needs to be improved again because the highest score is in the good category.

e. Communication skills

For the ability to communicate, the use of graduates gave an assessment that the good category was the highest with a percentage of $60.63 \%$ or a number of 97 people and very good 58 people or $36.25 \%$ and a sufficient category of $3.13 \%$ or a total of 5 people. This shows that the communication skills of graduates need to be improved in order to achieve excellent assessments

f. Teamwork

For the assessment of teamwork, it has not shown a high level of satisfaction, namely $38.75 \%$ choosing very good or 62 people and 58.13 , namely 93 people who were declared good and the rest was sufficient, namely $3.13 \%$ or 5 people

g. Self development

The ability of alumni to develop themselves is included in the good category of 66 , $88 \%$ or 107 people and the very good category is $26.88 \%$, namely 43 people and $6.25 \%$ or 10 people with the sufficient category.

\section{Conclusion}

The assessment for graduates about integrity, professionalism, ability to use information technology, communication skills, teamwork, and self-development is already very good and good. However, the English language skills of the graduates of the Muhammadiyah University 
of Magelang in 2018 were still low, 57 alumni with sufficient assessments and 11 people with poor assessments. It is hoped that this will become a reference for improving the curriculum and increasing English learning so that it is relevant to the needs of current graduate users.

\section{Acknowledgement}

This research was funded by APBU University of Muhammadiyah Magelang in 2019/2020. We would like to thank LPPM Muhammadiyah University of Magelang who has provided a lot of assistance and support so that this research can be completed from the beginning to publication. Thank you also to the team who helped the completion of this research

\section{References}

[1] I. Setyaningsih and M. Abrori, "Tingkat Kepuasan Pengguna Lulusan," Ilmiah Teknik Industri, vol. 12, no. 01, pp. 73-82, 2013.

[2] M. Setiyo et al., "Industry 4.0: Challenges of Mechanical Engineering for Society and Industry," Mechanical Engineering for Society and Industry, vol. 1, no. 1, pp. 3-6, 2021.

[3] Hermansyah, Eliana, and Dahrizal, "Kepuasan User ( Institusi Pengguna ) Terhadap Mutu," Jurnal Media Kesehatan, vol. 5, no. 1, pp. 01-100, 2009.

[4] N. Zafarina, "Studi Kepuasan Pengguna Lulusan Program Studi Pendidikan Teknik Bangunan Universitas Negeri Jakarta Di Bidang Kependidikan," Jurnal Pendidikan Teknik Sipil (JPenSil, vol. 2020, no. 2, pp. 81-90, 2020, doi: 10.21009/jpensil.v9i2.12091 A.

[5] F. Razak and R. Kamaruddin, "Global Science Education Journal," vol. 1, no. November, pp. 194 203, 2019.

[6] Wahyudin, "Peningkatan Mutu Dan Relevansi Perguruan Tinggi Melalui Tracer Study," JurnalCompetitiveness, vol. 10, pp. 91-100, 2016.

[7] Suwito, S. Yahya, and A. Hidayat, "Pengembangan Sistem Dan Pelaksanaan Tracer Study Alumni Iain Purwokerto Tahun 2014-2016," Jurnal Manajemen Pendidikan, vol. 502, no. 03, pp. 507-526, 2017.

[8] B. Kisworo, U. Utsman, I. Ilyas, and Y. Siswanto, "Kepuasan Mahasiswa dan Pengguna Lulusan Program Studi Pendidikan Luar Sekolah Universitas Negeri Semarang,” vol. 2, no. 2, pp. 150-156, 2018. 